Retraction

\title{
Retracted: A Simple, Sensitive Spectrophotometric Determination of Mosapride in Pharmaceutical Preparations Using Novel Reagent
}

\author{
Journal of Chemistry \\ Received 19 September 2020; Accepted 19 September 2020; Published 2 December 2020 \\ Copyright (C) 2020 Journal of Chemistry. This is an open access article distributed under the Creative Commons Attribution \\ License, which permits unrestricted use, distribution, and reproduction in any medium, provided the original work is \\ properly cited.
}

Journal of Chemistry has retracted the article titled "A Simple, Sensitive Spectrophotometric Determination of Mosapride in Pharmaceutical Preparations Using Novel Reagent" [1], as it was submitted for publication without the knowledge and approval of the co-authors G. Krishnamurthy Naidu, K. Suvardhan, M.V. Jyothi, and B.S. Sastry.

\section{References}

[1] G. K. Naidu, K. Suvardhan, M. V. Jyothi, B. S. Sastry, and P. Chiranjeevi, "A Simple, Sensitive Spectrophotometric Determination of Mosapride in Pharmaceutical Preparations Using Novel Reagent," E-Journal of Chemistry, vol. 1, no. 5, pp. 267-271, 2004. 